\title{
Biological and Health-promoting Activity of Vinification By- products Produced in Spanish Vineyards
}

J. Anter ${ }^{1}$, S. Demyda-Peyras ${ }^{1}$, M. del Pilar Delgado de la Torre ${ }^{2}$, J. Campos-Sanchez ${ }^{1}$, M.D. Luque de Castro ${ }^{2}$, A. MuñozSerrano $^{1}$, Á. Alonso-Moraga ${ }^{1 *}$

(1) Department of Genetics, University of Córdoba, Campus Rabanales, 14071 Córdoba, Spain

(2) Department of Analytical Chemistry, University of Córdoba, Campus Rabanales, 14071 Cordoba, Spain

Submitted for publication: June 2014

Accepted for publication: September 2014

Key words: Wine grape skin extracts, resveratrol, health-promoting activity, vinification by-products, Spanish vineyards

\begin{abstract}
Several by-products are produced in the Spanish agricultural system. Among them, fresh and vinified grape skins represent an abundant source of phenols with a potential nutraceutical value. Fresh grape skin extracts (FGSE) and vinification of grape skin extracts (VGSE) obtained by a microwave-assisted method have been chemically and biologically characterised. Their role in the maintenance of genetic stability was stated by in vivo genotoxic and antigenotoxic evaluations (Drosophilla melanogaster wing spot test), as well as by their potential chemopreventive effect (in an HL60 in vitro model). Total phenolic, anthocyanin and resveratrol contents were chemically characterised in the two extracts, showing some qualitative differences. Both extracts and resveratrol were not mutagenic in the Drosophila somatic mutation and recombination tests, and exerted antigenotoxic activities against hydrogen peroxide. They also showed cytotoxic activity to $\mathrm{HL} 60$ leukaemia cells, with an $\mathrm{IC}_{50}$ of $4.5 \mu \mathrm{L} / \mathrm{mL}, 4.6 \mu \mathrm{L} / \mathrm{mL}$ and $98 \mu \mathrm{M}$ respectively and induced apoptotic internucleosomic fragmentation in the HL60 cell line.
\end{abstract}

\section{INTRODUCTION}

Grapes (Vitis sp., Vitaceae) are the second most important fruit crop worldwide, with more than 69 million tons produced in 2011 (FAO). Of these, about $80 \%$ are vinified each year, generating approximately five to nine million tons of residues. These by-products are difficult to dispose of and sometimes may represent a serious environmental problem (Schieber et al., 2001). An alternative is their processing as an abundant and cheap source of phenolic compounds, widely appreciated for their health and nutritional properties (Iacopini et al., 2008). In this sense, one of the possibilities is the use of fresh and dried grape skin extracts as an infusion due to their nutraceutical and health-protecting properties (Cheng et al., 2010). However, to avoid potential health problems, the biological activity of these grape skin byproducts should be carefully characterised using in vitro and in vivo models (Iriti \& Faoro, 2009).

Polyphenols obtained from grapes and grape skins are normally separated into two principal groups: nonflavonoids (hydroxybenzoic and hydroxycinnamic acids and stilbenes) and flavonoids (flavan-3-ols, flavonols and anthocyanins) (Shi et al., 2003). It has been demonstrated widely that their phenolic composition and range depend, among other factors, on the grape variety (Kammerer et al., 2004), the grape growing and maturation conditions (Ojeda et al., 2002), the winemaking methodology employed (Sacchi, et al., 2005) and the treatment to obtain the skins
(Rodríguez Montealegre et al., 2006). These phenolic compounds showed an impairing capacity against the three steps of carcinogenesis by acting at multiple levels (Signorelli \& Ghidoni 2005). Their activity was observed in inhibiting phase I enzymes (avoiding damage at DNA level, the first step) (Chang et al., 2001), downregulating the expression of DNA methyltransferases and PGE2 cancerpromoting prostaglandin (Zhu et al., 2012a) and modulating the mitogenic signalling and cell growth (the second step), and inducing apoptosis and cellular G1 arrest (the third step) (Agarwal et al., 2000).

One of these major phenolic compounds observed in most of the wine by-products is the resveratrol $(3,4$ ',5-trihydroxytrans-stilbene), a phytoalexin that showed DNA-protective effects against $\mathrm{H}_{2} \mathrm{O}_{2}$-induced damage and cytotoxic effects in in vitro and in vivo assays (Rotondo et al., 1998; Baur \& Sinclair, 2006). In addition, resveratrol is recognised by its ability to prevent protein oxidation and platelet aggregation and to inhibit cyclooxygenases (Subbaramaiah et al., 1999). Furthermore, this compound is also widely studied as a promising nutraceutical molecule with a key role against carcinogenesis and cardiovascular diseases (Signorelli \& Ghidoni, 2005; Ruan et al., 2012).

However, all new complex mixtures with a potential use as nutraceuticals must be tested against possible mutagenic and toxic effects. For this purpose, one of the most employed methodologies is the somatic mutation and recombination

*Corresponding author: E-mail address: sebass@uco.es [Tel.: +34 957 218674; Fax: +34 957212072$]$

Acknowledgements: We thank Lic. Adriana Di Maggio for language editing 
test (SMART), performed in imaginal discs of the Drosophila melanogaster larvae. The so-called "wing spot test" is a reliable procedure to evaluate the genotoxicity of single compounds and complex mixtures due to the bio-activation competence observed in the larvae (Graf et al., 1994). With this in vivo methodology, we analysed the capability of grape extracts to inhibit the mutagenicity induced by a genotoxic oxidative model $\left(\mathrm{H}_{2} \mathrm{O}_{2}\right)$.

Furthermore, the cytotoxic and pro-apoptotic effects of these phenolic compounds against the carcinogenic process were determined employing the human promyelocytic leukemic (HL60) cell in vitro model (Birnie, 1988). This methodology was widely employed by our group to quantify the beneficial effects of several natural mixtures belonging to the "Mediterranean diet" against cancer development in humans (Anter et al. 2011; Anter et al., 2014).

Therefore, the aims of this study were: 1) to characterise the phenolic compounds presents in two different grape skin extracts obtained from Spanish wineries and 2) to assess the biological activity of grape skin extracts and resveratrol regarding their role in the maintenance of genetic stability and their potential chemopreventive effects as a required step before their potential use in the nutraceutical industry.

\section{MATERIAL AND METHODS \\ Samples}

Fresh grape skins and skins from the vinification marcs were collected from Syrah red grapes (Vitis vinifera) grown in the Andalusian region of Sierra de Segura, Spain. Fresh grapes were de-stalked and the skins were removed manually. Grape skins from vinification residues (marcs) were obtained directly in the winery after the grape juice had been collected after the initial winemaking maceration.

\section{Microwave-assisted extraction (MWE)}

The working conditions for the extraction of the target compounds from grape skins were: $12.5 \mathrm{~g}$ of the raw material extracted with $100 \mathrm{~mL} \mathrm{60 \%} \mathrm{(v/v)} \mathrm{aqueous} \mathrm{ethanol}$ at $\mathrm{pH}$ 4. Microwave irradiation at $140 \mathrm{~W}$ was applied for 10 min according to our laboratory method (Pérez-Serradilla \& Luque de Castro, 2011).

\section{Analytical methods}

All the chemical determinations and characterisations that are reported in this manuscript were carried out in the laboratory for metabolomics/proteomics and the exploitation of agricultural food residues at the University of Córdoba. Unless a different brand is described, reagents were purchased from Sigma Aldrich, Spain. More information is available in the supplementary information at the end of this article.

\section{Determination of total phenolic compounds by the Folin- Ciocalteu $(\mathrm{F}-\mathrm{C})$ method}

Total phenol compounds in the extracts were quantified by the $\mathrm{F}-\mathrm{C}$ method using gallic acid as standard. The results are expressed as equivalent to milligrams of gallic acid per $\mathrm{mL}$ of raw material extract (mg GAE/mL).

\section{Determination of total anthocyanin content}

The total concentration of anthocyanins in the extracts was estimated spectrophotometrically by monitoring the absorbance of the extract at $535 \mathrm{~nm}$, the selective wavelength for the target compounds in the extracts. The concentration of anthocyanins was expressed in $\mathrm{mg}$ equivalents of $\mathrm{P} 3 \mathrm{G} / \mathrm{g}$ (mg P3G/g) of dry weight.

\section{HPLC analysis}

The extracts from the raw materials were dried in a rotary evaporator to half their initial volume to remove ethanol. To avoid any loss of volatile phenols, the entire evaporation process was carried out at a controlled temperature of $20^{\circ} \mathrm{C}$. After that, all extracts were centrifuged for $10 \mathrm{~min}$ at $850 \mathrm{~g}$ to separate the solid residue from the extracts. Finally, each extract was filtered using a $0.45 \mu \mathrm{m}$ filter before injection into the chromatograph.

Individual separation of phenols in the extract was performed on an Inertsil ODS-2 column $(250 \mathrm{~mm} \times 4.6 \mathrm{~mm}$ i.d., $5 \mu \mathrm{m}$ particle, Análisis Vínicos, Tomelloso, Ciudad Real, Spain), using an injection volume of $20 \mu \mathrm{L}$ and a flow rate of $1 \mathrm{~mL} / \mathrm{min}$. Mobile phase A consisted of $0.2 \%$ $(\mathrm{v} / \mathrm{v})$ phosphoric acid aqueous solution and mobile phase B consisted of methanol. The gradient method was as follows: from $96 \%$ to $82 \% \mathrm{~A}$ in $20 \mathrm{~min}$, held for $20 \mathrm{~min}$, from $82 \%$ to $74 \% \mathrm{~A}$ in $24 \mathrm{~min}$ and from $74 \%$ to $50 \% \mathrm{~B}$ in $9 \mathrm{~min}$. The analytes were identified by comparing both their retention times and UV spectra with those of the corresponding standards. The absorption wavelengths were set at $260 \mathrm{~nm}$ for monitoring ellagic acid; at $280 \mathrm{~nm}$ for hydroxybenzoic acids, catechin and phenolic aldehydes; at $320 \mathrm{~nm}$ for hydroxycinnamic acids, and at $360 \mathrm{~nm}$ for hydroxycinnamic aldehydes.

\section{Genotoxicity and antigenotoxicity assays (SMART) Strains}

Two Drosophila strains were used: (i) $m w h / m w h$, carrying the recessive mutation $m$ wh (multiple wing hairs) that produces multiple tricomas per cell (Yan et al., 2008); and (ii) $f r^{3} /$ In (3LR) TM3, ri p pep bx $x^{34 e} e^{s} B d^{S}$, where the $f r^{3}$ (flare) marker is a homozygous recessive lethal mutation viable in homozygous somatic cells that produces deformed tricomas (Ren et al., 2007). Detailed information on the rest of the genetic markers is available in Lindsley and Zimm (1992).

\section{Treatments}

The SMART assay, developed by Graf et al. (1984), was carried out following our standard procedure (Anter et al., 2014). Briefly, $m w h / m w h$ males and $f r^{3} / T M 3$ virgin females were allowed to mate for two days. After eight hours of egg laying, the $72 h$-transheterozygous synchronised larvae were reared until pupation in glass vials containing $0.85 \mathrm{~g}$ of Drosophila Instant Medium (Formula 4-24, Carolina Biological Supply, Burlington, NC), supplemented with the tested compounds at two different concentrations: Fresh grape skin extracts (FGSE; 1.25 to $20 \mu \mathrm{L} / \mathrm{mL}$ ), vinification grape skin extracts (VGSE: 1.25 to $20 \mu \mathrm{L} / \mathrm{mL}$ ) and resveratrol (33 to $528 \mu \mathrm{M})$ ). The range of resveratrol concentrations employed corresponds to the content determined in the extracts (Table 1). Concurrent negative $\left(\mathrm{H}_{2} \mathrm{O}\right)$ and positive 
TABLE 1

Phytochemical profile of fresh grape skin extract (FGSE) and vinification grape skin extract (VGSE).

\begin{tabular}{lll}
\hline Target compound & $\begin{array}{l}\text { Concentration in } \\
\text { fresh grape skin } \\
\text { extracts (FGSE) }\end{array}$ & $\begin{array}{l}\text { Concentration in } \\
\text { vinification grape skin } \\
\text { extracts }(\text { VGSE) }\end{array}$ \\
\hline Caffeic acid & $0.57 \pm 0.00$ & $0.54 \pm 0.03$ \\
Coumaric acid & n.d. & n.d. \\
Resveratrol & $4.39 \pm 0.00$ & $5.40 \pm 0.07$ \\
Cyanidin & $101.0 \pm 0.2$ & $21.99 \pm 0.6$ \\
Myricetin & $5.57 \pm 0.05$ & $2.15 \pm 0.06$ \\
Quercetin & $0.89 \pm 0.02$ & $1.18 \pm 0.01$ \\
Kaempferol & $0.30 \pm 0.00$ & $0.24 \pm 0.03$ \\
Total anthocyanin content & $(2)$ & $43.47 \pm 0.03$ \\
Total phenolic content ${ }^{(3)}$ & $97.57 \pm 0.04$ & $1616.82 \pm 1$ \\
\hline
\end{tabular}

Notes: ${ }^{(1)}$ Expressed as mg/mL. ${ }^{(2)}$ Expressed as mg equivalents of peonidin-3-glucoside/g (mg P3G/g) of dry weight. ${ }^{(3)}$ Expressed as equivalent to milligrams of gallic acid per $\mathrm{mL}$ of raw material extract $(\mathrm{mg} \mathrm{GAE} / \mathrm{mL})$. n.d. $=$ no data

controls (0.12 M hydrogen peroxide, Sigma, H1009) were run.

The antigenotoxicity test was performed following the method described by Graf et al. (1998). Larvae were reared following the same protocol described previously in cotreatment with $0.12 \mathrm{M} \mathrm{H}_{2} \mathrm{O}_{2}$ as mutagenic agent.

Upon hatching, flies were fixed in $70 \%$ ethanol and the $m w h / f l r^{3}$ wings were mounted on slides and analysed using a $400 \mathrm{x}$ bright field microscope. Both the ventral and dorsal surfaces of the wings were analysed. Mutations were characterised as small single spots (one or two cells), large single spots (more than two cells) of either $m w h$ or flare, and twin spots (mwh-flare). Small and large spots can originate from somatic point mutation, chromosome aberration as well as somatic recombination, whilst twin spots are produced exclusively by somatic recombination between the $f r^{3}$ locus and the centromere.

\section{Data evaluation and statistical analysis}

The treatment series were compared with concurrent water control using the multi-decision procedure described by Frei and Wurgler (1995) to determine whether the result was positive, inconclusive or negative.

In the co-treatments with $\mathrm{H}_{2} \mathrm{O}_{2}$, the inhibition percentage of FGSE, VGSE and resveratrol for total spots was calculated as described by Abraham (1994):

$$
\mathrm{P}=\frac{\mathrm{TSG}-\mathrm{TSGP}}{\mathrm{TSG}} \times 100
$$

$\mathrm{TSG}=$ total spots of genotoxin alone; $\mathrm{TSGP}=$ total spots of genotoxin and tested product

\section{Cytotoxicity assays}

\section{Cell culture}

Cells were cultured in RPMI 1640 medium (Biowhittaker, BE12-167F), supplemented with $10 \%$ heat-inactivated bovine serum (Biowhittaker, DE14-801F), 200 mM L-glutamine (Sigma, G7513) and an antibiotic-antimitotic solution with 10000 units of penicillin, $10 \mathrm{mg}$ of streptomycin and $25 \mu \mathrm{g}$ amphotericin B per mL (Sigma, A5955), using tissue culture plastics from Techno Plastic Products AG (Switzerland). Cells were grown at $37^{\circ} \mathrm{C}$ in a humidified $95 \%$ air $-5 \% \mathrm{CO}_{2}$ atmosphere and sub-cultured three times per week.

\section{Assessment of cell viability}

HL60 cells were placed in 12-well culture plates at $2 \times 10^{5}$ cells $/ \mathrm{mL}$ and treated for $72 \mathrm{~h}$ with different concentrations of extracts and resveratrol ( 5 to $20 \mu \mathrm{L} / \mathrm{mL}$ and 33 to $528 \mu \mathrm{M}$ respectively). The cell viability was assessed by the trypan blue exclusion method following our standard procedure (Anter et al., 2011). The percentage of unstained (viable) and stained (dead) cells and the $\mathrm{IC}_{50}$ values were determined in three independent replicates.

\section{Analysis of DNA fragmentation}

Suspension cultures of HL60 cells $\left(1.5 \times 10^{6}\right.$ cells/well $)$ were treated with FGSE ( 1 to $20 \mu \mathrm{L} / \mathrm{mL}$ ), VGSE (1 to $20 \mu \mathrm{L} / \mathrm{mL}$ ) and resveratrol (33 to $528 \mu \mathrm{M}$ ) for $5 \mathrm{~h}$. The cells were centrifuged at $956 \mathrm{~g}$ for $5 \mathrm{~min}$ and washed with phosphatebuffered saline solution. The DNA was extracted using a commercial DNA extraction kit (Dominion mbl, MBL 243), and treated with RNase. A final amount of 1500 ng of DNA of each treatment was resolved by electrophoresis at $50 \mathrm{~V} / \mathrm{cm}$ for $120 \mathrm{~min}$ on $2 \%$ agarose gel impregnated with ethidium bromide. A DNA molecular weight reference (Dominion mbl, MBL 021) was run in parallel and DNA fragments were visualised under UV light.

\section{RESULTS AND DISCUSSION}

\section{Phenolic content of grape skin extracts}

Table 1 shows the phytochemical profile of fresh grape skin extract (FGSE) and vinification grape skin extract (VGSE). Our results showed a higher total phenolic content (1 555.33 in FGSE and 1616.82 in VGSE) and total anthocyanin content (97.573 in FGSE and 43.473 in VGSE) in comparison with previous studies (Thimothe et al., 2007; Anastasiadi et al., 2012) performed in different cultivars. Furthermore, kaempferol (0.245 and $0.302 \mathrm{ppm})$ and total anthocyanin contents (43.47 and $97.57 \mathrm{mgP} 3 \mathrm{G} / \mathrm{g}$ ) were also higher than those reported previously by Zhu et al. (2012b) 
and Muñoz et al. (2008). This could be due to the fact that phenolic content is strongly influenced by the grape variety, vintage year (Kallithraka et al., 2009) and extraction method (Delgado-Torre et al., 2012), and therefore the comparison between studies must be considered carefully. On the other hand, our results showed a much lower concentration of cyanidin (21.9 vs 101.0), myricetin (2.15 vs 5.57) and total anthocyanin content (43.473 vs 97.573) in VGSE compared to FGSE. This could be due to the fact that a large part of these anthocyanins (more than 50\%) are transferred to the wine during maceration and winemaking (Van Balen, 1984), lowering the percentage observed in the by-products. In contrast, resveratrol (5.402 vs $4.388 \mathrm{ppm}$ ) and quercetin (1.185 vs $0.892 \mathrm{ppm}$ ) concentrations were higher in VGSE compared to FGSE. We suggest that these results could have been obtained due to the fact that the molecules migrate from the grape seeds and pomace to the skin by-products during winemaking, increasing their concentration. However, it is noteworthy that the differences observed were statistically not significant. Finally, resveratrol concentrations were much higher than those reported previously by Priego-Capote et al. (2007), who obtained only $0.71 \mu \mathrm{g} / \mathrm{mL}$ of grape skin extract. We speculate that the extraction procedure (Malovaná et al., 2001) and the different oenological practices and cultivars (Jeandet et al., 1995) could be responsible for these large differences, and consequently any attempt to trade these kinds of raw materials has to pass through a standardisation process.

\section{Genotoxic/antigenotoxic potential of FGSE, VGSE and resveratrol}

Transheterozygous larvae of Drosophila were treated with FGSE (1.25 to $20 \mu \mathrm{L} / \mathrm{mL}$ ), VGSE (1.25 to $20 \mu \mathrm{L} / \mathrm{mL}$ ) and resveratrol (33 to $528 \mu \mathrm{M})$ to assess the lack of genotoxicity of these compounds on the genomic structure (Table 2). Hydrogen peroxide showed a mutation frequency of 0.57 with a significant increment of all spot categories when compared to the water control (0.27). Romero-Jiménez et al. (2005) showed that $\mathrm{H}_{2} \mathrm{O}_{2}$ is genotoxic in the SMART and increases single and multiple spots in Drosophila melanogaster due to genetic damage. In addition, $\mathrm{H}_{2} \mathrm{O}_{2}$ is an endogenous mutagen responsible for some of the most important cancer risks associated with persistent inflammations (Fitzpatrick, 2001). Oxy-radicals derived from $\mathrm{H}_{2} \mathrm{O}_{2}$ can act either directly on the genome, causing oncogenic mutations derived from chromosome damage (Burcham, 1999), or indirectly, by modulating gene transcription (Cerda \& Weitzman, 1997) and suppressing genomic repair pathways (Hu et al., 1995; Ghosh \& Mitchell, 1999). The genotoxic results for $\mathrm{H}_{2} \mathrm{O}_{2}$ validate it as an appropriate genotoxicant in SMART for screening between oxidative mutagens (positive controls as $\mathrm{H}_{2} \mathrm{O}_{2}$ ) and non-mutagens (distilled sterile water controls or potentially safe extracts).

Table 2 shows the results of genotoxicity assays for FGSE, VGSE and resveratrol. The three substances analysed were non-mutagenic, as the number of total spots per wing was not significantly different from the water control value (0.27). It is noteworthy that there are no previous studies evaluating vinification by-products using the SMART assay. However, these results agree with previous studies performed using different genotoxicity tests, like the Salmonella/microsome assay (Aiub et al., 2004) and those performed in laboratory rats (Lluís et al., 2011). These results are important in order to evaluate the use of this kind of by-products as a nutraceutical supplement. Furthermore, the tested compounds also counteracted the mutagenic effect of $\mathrm{H}_{2} \mathrm{O}_{2}$ in the antigenotoxicity test performed in Drosophila melanogaster larvae co-incubated with hydrogen peroxide (Table 3). Both grape skin extracts (FGSE, VGSE) and resveratrol showed negative results, indicating desmutagenic properties. These results are also in agreement with previous reports showing that these substances inhibit $\mathrm{H}_{2} \mathrm{O}_{2}$-induced mutagenicity, mainly by scavenging free radicals (Stagos et al., 2006). In this sense, a previous study also showed protective effects of commercial grape proanthocyanidins against the DNA damage induced by doxorubicin, a

TABLE 2

Summary of genotoxicity results obtained in the Drosophila wing spot test (SMART) for fresh grape skin extract (FGSE), vinification grape skin extract (VGSE) and resveratrol.

\begin{tabular}{llllll}
\hline Compounds & $\begin{array}{l}\text { Number of } \\
\text { wings }\end{array}$ & $\begin{array}{l}\text { Small spots } \\
(1-2 \text { cells }) \mathrm{m}=2\end{array}$ & $\begin{array}{l}\text { Large spots } \\
\text { (more than two cells) } \mathrm{m}=5\end{array}$ & $\begin{array}{l}\text { Twin spots } \\
\mathrm{m}=5\end{array}$ & $\begin{array}{l}\text { Total spots } \\
\mathrm{m}=2\end{array}$ \\
\hline Negative control & 40 & $0.23(9)$ & $0.06(2)$ & 0 & $0.27(11)$ \\
$\mathrm{H}_{2} \mathrm{O}_{2}(0.12 \mathrm{M})$ & 40 & $0.53(21)$ & $0.03(1)$ & $0.03(1)$ & $0.57(23)+^{*}$
\end{tabular}

\begin{tabular}{|c|c|c|c|c|c|}
\hline \multicolumn{6}{|c|}{ FGSE (mL/mL) } \\
\hline 1.25 & 40 & $0.17(7)$ & $0.05(2)$ & 0 & $0.22(9)-$ \\
\hline 20 & 40 & $0.20(8)$ & $0.03(1)$ & 0 & $0.22(9)-$ \\
\hline \multicolumn{6}{|c|}{ VGSE $(\mathrm{mL} / \mathrm{mL})$} \\
\hline 1.25 & 40 & $0.28(11)$ & 0 & 0 & $0.27(11)-$ \\
\hline 20 & 40 & $0.20(8)$ & 0 & 0 & $0.20(8)-$ \\
\hline \multicolumn{6}{|c|}{ Resveratrol (mM) } \\
\hline 33 & 40 & $0.15(6)$ & $0.03(1)$ & 0 & $0.17(7)-$ \\
\hline 528 & 40 & $0.15(6)$ & 0 & 0 & $0.15(6)-$ \\
\hline
\end{tabular}

${ }^{*}$ Statistical diagnoses according to Frei and Würgler $(1988,1995):+$ (positive), - (negative) and i (inconclusive). Significance levels $*=\mathrm{P}<0.05$, one-sided test without Bonferroni correction. 
TABLE 3

Summary of antigenotoxicity results obtained in the Drosophila wing spot test (SMART) for fresh grape skin extracts (FGSE), vinification grape skin extracts (VGSE) and resveratrol using hydrogen peroxide as genotoxicant.

\begin{tabular}{|c|c|c|c|c|c|c|}
\hline Compound & $\begin{array}{l}\text { Number of wings } \\
\mathrm{n}\end{array}$ & $\begin{array}{l}\text { Small spots } \\
(1-2 \text { cells }) \mathrm{m}=2\end{array}$ & $\begin{array}{l}\text { Large spots } \\
\text { (more than two } \\
\text { cells) } \mathrm{m}=5\end{array}$ & $\begin{array}{l}\text { Twin spots } \\
\mathrm{m}=5\end{array}$ & $\begin{array}{l}\text { Total spots } \\
\mathrm{m}=2\end{array}$ & $\begin{array}{l}\text { Inhibition } \\
\text { activity \% }\end{array}$ \\
\hline Negative control & 40 & $0.23(9)$ & $0.06(2)$ & 0 & $0.27(11)$ & \\
\hline $\mathrm{H} 2 \mathrm{O} 2(0.12 \mathrm{M})$ & 40 & $0.53(21)$ & $0.03(1)$ & $0.03(1)$ & $0.57(23)+*$ & \\
\hline \multicolumn{7}{|c|}{ COMBINED TREATMENT with H2O2 $(0.12 \mathrm{M})$} \\
\hline \multicolumn{7}{|l|}{ FGSE (mL/mL) } \\
\hline 1.25 & 40 & $0.10(4)$ & 0 & 0 & $0.10(4)-$ & 82.75 \\
\hline 20 & 40 & $0.18(7)$ & $0.07(3)$ & 0 & $0.25(10)-$ & 56.89 \\
\hline \multicolumn{7}{|l|}{ VGSE (mL/mL) } \\
\hline 1.25 & 40 & $0.22(9)$ & $0.02(1)$ & 0 & $0.25(10)-$ & 56.89 \\
\hline 20 & 40 & $0.18(7)$ & $0.06(2)$ & $0.03(1)$ & $0.25(10)-$ & 56.89 \\
\hline \multicolumn{7}{|c|}{ Resveratrol (mM) } \\
\hline 33 & 40 & 5 & 0 & $0.03(1)$ & $0.15(6)-$ & 74.13 \\
\hline 528 & 40 & $0.10(4)$ & 0 & 0 & $0.10(4)-$ & 82.75 \\
\hline
\end{tabular}

*Statistical diagnoses according to Frei and Würgler (1988, 1995): + (positive), - (negative) and i (inconclusive). Significance levels $*=\mathrm{P}<0.05$, one-sided test without Bonferroni correction.

generator of free radical metabolites (De Rezende et al., 2009). However, it has also been demonstrated that grape extracts could also act against this kind of DNA damage by alternative pathways such as selective $\mathrm{Fe}+$ binding (Osowski et al., 2010). Our results also confirm the protective action of resveratrol alone against oxidative damage, as has been demonstrated widely over the past few years in different studies (Leonard et al., 2003; Masaki, 2010). Furthermore, we obtained the same effects comparing the anti-oxidative action of all the polyphenols detected in the by-products and resveratrol. This result could be due to the fact that resveratrol is considered one of the molecules with a higher biological activity in wines and grapes (Soleas et al., 1997). Nevertheless, and contrary to our results, some authors have demonstrated a differential effect between grape extracts and their individual components, probably explained by a synergism between polyphenolic compounds (Stagos et al., 2006).

The inhibition percentage, which constitutes a measure of the antigenotoxic capabilities of a particular compound against the genetic damage produced by hydrogen peroxide, is also shown in Table 3. It was noteworthy that only resveratrol and FGSE were able to inhibit that damage up to $80 \%$. In contrast, VGSE only reached an inhibition percentage of $55 \%$. This difference in ability to avoid genetic damage in the imaginal cell discs of Drosophila can be explained by the fact that large amounts of the antioxidant compounds of VGSE were transferred to the wine during the winemaking process (Guadalupe \& Ayestarán, 2008).

\section{Effects of FGSE, VGSE and resveratrol on cell viability} Cytotoxic and proapoptotic effects of fresh and vinification grape skin extracts were assayed in the HL60 human leukaemia cell line. Both compounds showed a high cytotoxic effect $\left(\mathrm{IC}_{50} \approx 4.5 \mu \mathrm{L} / \mathrm{mL}\right.$ ) as well as resveratrol $\left(\mathrm{IC}_{50} \approx 98\right.$ $\mu \mathrm{M}$ ) in a dose-dependent manner (Fig. 1). These results are in consonance with similar effects observed in HL60 using table grape skin extracts (Clément et al., 1998; Anter et al., 2011). It has been demonstrated that grape phenols can affect several metabolic pathways in cancer cells (King et al., 2006). Among them, apoptosis is more desirable for chemoprevention since it could be the mechanism with less side effects. As shown in Fig. 2, FGSE, VGSE and resveratrol, supplemented at high concentrations, induced a cleavage of chromosomal DNA into oligonucleosomal fragments, which is well known as an apoptosis marker. This induction of apoptotic cell death could explain the cytotoxic properties observed, supporting the hypothesis that the anticarcinogenic effects of FGSE, VGSE and resveratrol may be mediated by this particular pathway (Stervbo et al., 2006). In this sense, it has been reported that the apoptotic induction produced by resveratrol in HL60 cells is mediated mainly by increasing caspase activity, leading to the occurrence of these characteristic morphological changes (Garvin et al., 2006). Furthermore, it has also been demonstrated that resveratrol can downregulate $B c l 2$ expresison and upregulate Bax expression (Zhan et al., 1994; Roman et al., 2002), two major genes involved in the apoptotic pathway. Another possible explanation is the enhancement of p53 activity and expression via a Ras-MAPK kinase signal transduction pathway produced by resveratrol (Huang et al., 1999). Since the lack of p53 activity was pointed out as one of the main causes of chemotherapy resistance in cancer cells (Fisher, 1994), this improved activity could also be responsible for the pro-apoptotic effect against HL60 by FGSE and resveratrol observed in the present study.

\section{CONCLUSIONS}

Our results show some potential advantages of the use of FGSE and VGSE as food additives and/or nutraceuticals, as they exhibit pleiotropic biological effects and show three important biological capabilities: 1) they were characterised as non-mutagenic and desmutagenic in a robust in vivo model; 2) they show acceptable inhibition competences 

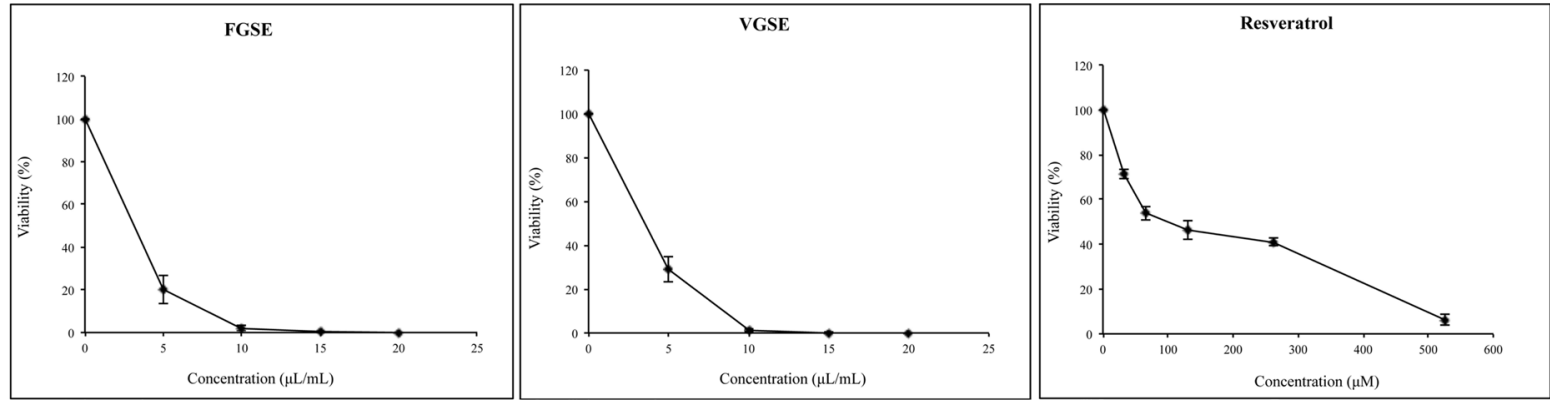

FIGURE 1

Viability of HL60 cells treated with fresh grape skin extract (FGSE), vinification grape skin extract (VGSE) and resveratrol for $72 \mathrm{~h}$. The data are expressed as percentage of control (mean \pm SD) from three independent experiments.

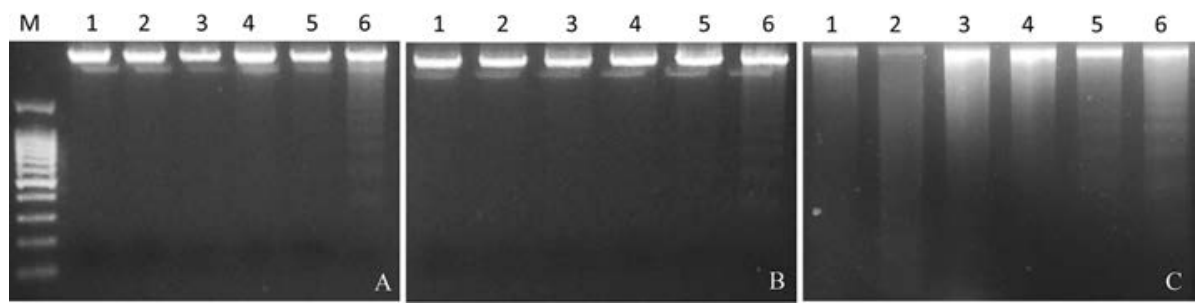

FIGURE 2

Nucleosomal DNA fragmentation in HL60 cells treated for $5 \mathrm{~h}$ with fresh grape skin extract (FGSE), vinification grape skin extract (VGSE) and resveratrol. DNA fragmentation was detected following electrophoresis in agarose gel and staining with ethidium bromide. Fig. 2A: FGSE. Control (lane 1), $1 \mu \mathrm{L} / \mathrm{mL}$ (lane 2), $5 \mu \mathrm{L} / \mathrm{mL}$ (lane 3), $10 \mu \mathrm{L} / \mathrm{mL}$ (lane 4), $15 \mu \mathrm{L} / \mathrm{mL}$ (lane 5) and $20 \mu \mathrm{L} / \mathrm{mL}$ (lane 6). Fig. 2B: VGSE. Control (lane 1), $1 \mu \mathrm{L} / \mathrm{mL}$ (lane 2), $5 \mu \mathrm{L} / \mathrm{mL}$ (lane 3), $10 \mu \mathrm{L} / \mathrm{mL}$ (lane 4), $15 \mu \mathrm{L} / \mathrm{mL}$ (lane 5) and $20 \mu \mathrm{L} / \mathrm{mL}$ (lane 6). Fig. 2C: resveratrol. Control (lane 1), 33 7M (lane 2), 66 7M (lane 3), 132 7M (lane 4), 264 $7 \mathrm{M}$ (lane 5) and $5287 \mathrm{M}$ (lane 6). M indicates DNA size marker

against oxidation-induced genetic damage and 3) they show an important cytotoxic and pro-apoptotic effect against a human cancer cell line. With this potential use of vinification waste, the pharmaceutical and/or nutraceutical industries could obtain an interesting and low-cost source of antioxidant compounds and wineries could reutilise and recycle the most important by-product generated during the commercial winemaking process.

\section{SUPPLEMENTARY INFORMATION}

(+)-Catechin, vanillin(4-hydroxy-3-methoxybenzaldehyde), quercetin(2-(3,4-dihydroxyphenyl)-3,5,7-trihydroxy-4H-1benzopyran-4-onedihydrate, 3,3',4',5,7-pentahydroxyflavone dehydrate), kaempferol(3,4',5,7-tetrahydroxyflavone, 3,5,7-tri-hydroxy-2-(4-hydroxyphenyl)-4H-1-benzopyran-4-one), caffeic acid(3,4-dihydroxycinnamic acid), resveratrol(3,4',5-trihydroxy-trans-stilbene, 5-[(1E)-2(4-hydroxyphenyl)ethenyl]-1,3-benzenediol), cyanidin (3,3', 4,5,7-pentahydroxyflavylium chloride), myricetin $\left(3,3^{\prime}, 4^{\prime}, 5,5^{\prime}, 7\right.$-hexahydroxyflavone, cannabiscetin), syringaldehyde(4-hydroxy-3,5-dimethoxybenzaldehyde), coniferaldehyde(4-hydroxy-3-methoxycinnamaldehyde), sinapaldehyde (4-hydroxy-3,5-dimethoxycinnamaldehyde), acetovanillone (1-(4-hydroxy-3-methoxyphenyl)-ethanone), acetosyringone(1-(4-hydroxy-3,5-dimethoxyphenyl)-ethanone), 5-hydroxymethylfurfural(5-hydroxymethyl-2-furancarboxaldehyde), pyrogallol(1,2,3-trihydroxybenzene), pyrocatechol(1,2-dihydroxybenzene), guaiacol (2-methoxyphenol) and gallic(3,4,5-trihydroxybenzoic acid), protocatechuic(3,4-dihydroxybenzoic acid), p-hydroxybenzoic, vanillic(4-hydroxy-3-methoxybenzoic acid), syringic(4-hydroxy-3,5-dimethoxybenzoic acid), p-coumaric(4-hydroxycinnamic acid), ferulic(4-hydroxy3-methoxycinnamic acid), and synapic acids (4-hydroxy3,5-dimethoxycinnamic acid) were from Sigma-Aldrich (St. Louis, USA), as was $p$-cresol (1-hydroxy-4-methylbenzene), used as external standard.

\section{Apparatus}

A Spectronic Helios Gamma Spectrometer (Termo Waltham, MA, USA) was used to monitor the absorbance of the extracts, and an F-2500 Hitachi Fluorescence Spectrophotometer (Pleasanton, Canada), equipped with a $10 \mathrm{~mm}$ path length cuvette, was used for monitoring the fluorescence in the ORAC assay.

Shaking and centrifugation of the extracts were carried out by means of an MS2 Minishaker (IKA, Germany) Vortex and a Mixtasel (Selecta, Barcelona, Spain) centrifuge, respectively.

A Microdigest 301 digestor of $200 \mathrm{~W}$ maximum power, from Prolabo (Paris, France), was used to accelerate solidliquid extraction.

Individual separation of the extract components was carried out by a high-performance liquid chromatograph - 
a ProStar 410 autosampler equipped with a $0.5 \mathrm{~mL}$ sample loop (Varian, Palo Alto, California, USA), connected on-line with a liquid chromatograph (Varian, 240 pump) - and monitored by a 330 Varian PDA detector at the optimal wavelength for each component. Data processing was carried out using Star Chromatography Workstation version 5.52 software running on a personal computer. Characterisation of the spectra and the assessment of peak purity were performed by polyview-2000 software.

\section{Reagents}

Ethanol (96\% v/v) PA from Panreac (Barcelona, Spain), methanol (HPLC grade) and phosphoric acid (both supplied by Panreac), and n-hexane (LiChrosolv, Merck, Darmstadt, Germany), Folin-Ciocalteu reagent, sodium carbonate, gallic acid and AAPH (2,2'-azobis-2-methyl-propanimidamide dihydrochloride) were from Sigma. All standards for the identification and quantitation of extract components were from Sigma-Aldrich (St. Louis, USA).

\section{LITERATURE CITED}

Abraham, S.K., 1994. Antigenotoxicity of coffee in the Drosophila assay for somatic mutation and recombination. Mutagenesis 9(4), 383-386.

Agarwal, C., Sharma, Y. \& Agarwal, R., 2000. Anticarcinogenic effect of a polyphenolic fraction isolated from grape seeds in human prostate carcinoma du145 cells: Modulation of mitogenic signaling and cell-cycle regulators and induction of g1 arrest and apoptosis. Mol. Carcinog. 28(3), $129-138$.

Aiub, C., Stankevicins, L., Da Costa, V., Ferreira, F., Mazzei, J., Ribeiro da Silva, A., Soares de Moura, R. \& Felzenszwalb, I., 2004. Genotoxic evaluation of a vinifera skin extract that present pharmacological activities. Food Chem. Toxicol. 42(6), 969-973.

Anastasiadi, M., Pratsinis, H., Kletsas, D., Skaltsounis, A.L. \& Haroutounian, S.A., 2012. Grape stem extracts: Polyphenolic content and assessment of their in vitro antioxidant properties. LWT-Food Sci. Technol. 48(2), 316-322.

Anter, J., De Abreu-Abreu, N., Fernandez-Bedmar, Z., Villatoro-Pulido, M., Alonso-Moraga, A. \& Munoz-Serrano, A., 2011. Targets of red grapes: Oxidative damage of DNA and leukaemia cells. Nat. Product Commun. $6(1), 59-64$.

Anter, J., Fernandez-Bedmar, Z., Villatoro-Pulido, M., Demyda-Peyras, S., Moreno-Millan, M., Alonso-Moraga, A., Munoz-Serrano, A. \& Luque de Castro, M.D., 2011. A pilot study on the DNA-protective, cytotoxic, and apoptosis-inducing properties of olive-leaf extracts. Mutat. Res.-Genet. Toxicol. Environ. Mutag. 723(2), 165-170.

Anter, J., Tasset, I., Demyda-Peyras, S., Ranchal, I., Moreno-Millan, M., Romero-Jimenez, M., Muntane, J., Luque de Castro, M.D., Munoz-Serrano, A. \& Alonso-Moraga, A., 2014. Evaluation of potential antigenotoxic, cytotoxic and proapoptotic effects of the olive oil by-product «alperujo», hydroxytyrosol, tyrosol and verbascoside. Mut. Res. Gen. Toxicol. Environ. Mutagen. 772, 25-33.

Baur, J.A. \& Sinclair, D.A., 2006. Therapeutic potential of resveratrol: The in vivo evidence. Nat. Rev. Drug Discov. 5(6), 493-506.

Birnie, G.D., 1988. The HL60 cell line: A model system for studying human myeloid cell differentiation. Br. J. Cancer 58(SUPPL. 9), 41-45.

Burcham, P.C., 1999. Internal hazards: Baseline DNA damage by endogenous products of normal metabolism. Mut. Res. 443(1-2), 11-36.

Cerda, S. \& Weitzman, S.A., 1997. Influence of oxygen radical injury on DNA methylation. Mut. Res. 386(2), 141-152.
Chang, T.K.H., Chen, J. \& Lee, W.B.K., 2001. Differential inhibition and inactivation of human CYP1 enzymes by trans-resveratrol: Evidence for mechanism-based inactivation of CYP1A2. J. Pharmacol. Exp. Ther. 299(3), 874-882.

Cheng, V.J., Bekhit Ael, D., Sedcole, R. \& Hamid, N., 2010. The impact of grape skin bioactive functionality information on the acceptability of tea infusions made from wine by-products. J. Food Sci. 75(4), S167-S172.

Clément, M.V., Hirpara, J.L, Chawdhury, S.H. \& Pervaiz, S., 1998. Chemopreventive agent resveratrol, a natural product derived from grapes, triggers CD95 signaling-dependent apoptosis in human tumor cells. Blood 92(3), 996-1002.

Delgado-Torre, M.P., Ferreiro-Vera, C., Priego-Capote, F., Pérez-Juan, P.M. \& Luque de Castro, M.D., 2012. Comparison of accelerated methods for the extraction of phenolic compounds from different vine-shoot cultivars. J. Agric. Food Chem. 60(12), 3051-3060.

De Rezende, A.A., Graf, U., Guterres Zda, R., Kerr, W.E. \& Spano, M.A. 2009. Protective effects of proanthocyanidins of grape (Vitis vinifera L.) seeds on DNA damage induced by Doxorubicin in somatic cells of Drosophila melanogaster. Food Chem. Toxicol. 47(7), 1466-1472.

Fisher, D.E., 1994. Apoptosis in cancer therapy: Crossing the threshold. Cell 78(4), 539-542.

Fitzpatrick, F.A., 2001. Inflammation, carcinogenesis and cancer. Int. Immunopharmacol. 1(9-10), 1651-1667.

Frei, H. \& Wurgler, F.E., 1988. Statistical methods to decide whether mutagenicity test data from Drosophila assays indicate a positive, negative, or inconclusive result. Mut. Res. 203(4), 297-308.

Frei, H. \& Wurgler, F.E., 1995. Optimal experimental design and sample size for the statistical evaluation of data from somatic mutation and recombination tests (SMART) in Drosophila. Mut. Res. 334(2), 247-258.

Garvin, S., Ollinger, K. \& Dabrosin, C., 2006. Resveratrol induces apoptosis and inhibits angiogenesis in human breast cancer xenografts in vivo. Cancer Lett. 231(1), 113-122.

Ghosh, R. \& Mitchell, D.L., 1999. Effect of oxidative DNA damage in promoter elements on transcription factor binding. Nucleic Acids Res. 27(15), 3213-3218.

Graf, U., Abraham, S.K., Guzman-Rincon, J. \& Würgler, F.E., 1998. Antigenotoxicity studies in Drosophila melanogaster. Mut. Res. 402(1-2), 203-209.

Graf, U., Alonso-Moraga, Á., Castro, R. \& Diaz Carrillo, E. 1994. Genotoxicity testing of different types of beverages in the Drosophila wing somatic mutation and recombination test. Food Chem. Toxicol. 32(5), 423430 .

Graf, U., Wurgler, F.E., Katz, A.J., Frei, H., Juon, H., Hall, C.B. \& Kale, P.G., 1984. Somatic mutation and recombination test in Drosophila melanogaster. Environ. Mutagen. 6(2), 153-188.

Guadalupe, Z. \& Ayestarán, B., 2008. Changes in the color components and phenolic content of red wines from Vitis vinifera L. cv. "tempranillo" during vinification and aging. Eur. Food Res. Technol. 228(1), 29-38.

Hu, J.J., Dubin, N., Kurland, D., Ma, B.L, \& Roush, G.C., 1995. The effects of hydrogen peroxide on DNA repair activities. Mut. Res. 336(2), 193-201.

Huang, C., Ma, W.Y, Goranson, A. \& Dong, Z., 1999. Resveratrol suppresses cell transformation and induces apoptosis through a p53-dependent pathway. Carcinogenesis 20(2), 237-242.

Iacopini, P., Baldi, M., Storchi, P. \& Sebastiani, L., 2008. Catechin, epicatechin, quercetin, rutin and resveratrol in red grape: Content, in vitro antioxidant activity and interactions. J. Food Compos. Anal. 21(8), 589-598.

Iriti, M. \& Faoro, F., 2009. Bioactivity of grape chemicals for human health. Nat. Prod. Commun. 4(5), 611-634. 
Jeandet, P., Bessis, R., Maume, B.F., Meunier, P., Peyron, D. \& Trollat, P., 1995. Effect of enological practices on the resveratrol isomer content of wine. J. Agric. Food Chem. 43(2), 316-319.

Kallithraka, S., Aliaj, L., Makris, D.P. \& Kefalas, P., 2009. Anthocyanin profiles of major red grape (Vitis vinifera L.) varieties cultivated in Greece and their relationship with in vitro antioxidant characteristics. Int. J. Food Sci. Technol. 44(12), 2385-2393.

Kammerer, D., Claus, A., Carle, R. Schieber, A. 2004. Polyphenol screening of pomace from red and white grape varieties (Vitis vinifera L.) by HPLCDAD-MS/MS. J. Agric. Food Chem. 52(14), 4360-4367.

King, R.E., Bomser, J.A. \& Min, D.B., 2006. Bioactivity of resveratrol. Compr. Rev. Food Sci. Food Safety. 5(3), 65-70.

Leonard, S.S., Xia, C., Jiang, B.H., Stinefelt, B., Klandorf, H., Harris, G.K. \& Shi, X., 2003. Resveratrol scavenges reactive oxygen species and effects radical-induced cellular responses. Biochem. Biophys. Res. Commun. 309(4), 1017-1026.

Lindsley, D.L. \& Zimm, G.G., 1992. The genome of Drosophila melanogaster. San Diego, Academic Press, Inc.

Lluís, L., Muñoz, M., Rosa Nogués, M., Sánchez-Martos, V., Romeu, M., Giralt, M., Valls, J. \& Solà, R., 2011. Toxicology evaluation of a procyanidin-rich extract from grape skins and seeds. Food Chem. Toxicol. 49(6), 1450-1454

Malovaná, S., F. J. García Montelongo, J. P. Pérez \& M. A. RodríguezDelgado, 2001. Optimisation of sample preparation for the determination of trans-resveratrol and other polyphenolic compounds in wines by high performance liquid chromatography. Anal Chim Acta 428(2): 245-253.

Masaki, H., 2010. Role of antioxidants in the skin: Anti-aging effects. J. Dermatol. Sci. 58(2), 85-90.

Muñoz, S., Mestres, M., Busto, O. \& Guasch, J., 2008. Determination of some flavan-3-ols and anthocyanins in red grape seed and skin extracts by HPLC-DAD: Validation study and response comparison of different standards. Anal. Chim. Acta 628(1), 104-110.

Ojeda, H., Andary, C., Kraeva, E., Carbonneau, A. \& Deloire, A., 2002. Influence of pre- and postveraison water deficit on synthesis and concentration of skin phenolic compounds during berry growth of Vitis vinifera cv. Shiraz. Am. J. Enol. Vitic. 53(4), 261.

Osowski, A., Pietrzak, M., Wieczorek, Z. \& Wieczorek, J., 2010. Natural compounds in the human diet and their ability to bind mutagens prevents DNA-mutagen intercalation. J. Toxicol. Environ. Health A. Curr. Iss. 73(1718), 1141-1149

Pérez-Serradilla, J.A. \& Luque de Castro, M.D., 2011. Microwave-assisted extraction of phenolic compounds from wine lees and spray-drying of the extract. Food Chem. 124(4), 1652-1659.

Priego-Capote, F., Rodríguez, J.M. \& Luque de Castro, M.D., 2007. Determination of phenolic compounds in grape skin by capillary electrophoresis with simultaneous dual fluorescence and diode array absorption detection after dynamic superheated liquid leaching. J. Chromatogr. A 1139(2), 301-307.

Ren, N., Charlton, J. \& Adler, P.N., 2007. The flare gene, which encodes the AIP1 protein of Drosophila, functions to regulate F-actin disassembly in pupal epidermal cells. Genetics 176(4), 2223-2234.

Rodríguez Montealegre, R., Romero Peces, R., Chacón Vozmediano, J., Martínez Gascuena, J. \& García Romero, E., 2006. Phenolic compounds in skins and seeds of ten grape Vitis vinifera varieties grown in a warm climate. J. Food Compos. Anal. 19(6-7), 687-693.

Roman, V., Billard, C., Kern, C., Ferry-Dumazet, H., Izard, J.C., Mohammad, R., Mossalayi, D.M. \& Kolb, J.P., 2002. Analysis of resveratrol-induced apoptosis in human B-cell chronic leukaemia. Br. J. Haematol. 117(4), 842851 .
Romero-Jiménez, M., Campos-Sánchez, J., Analla, M., Muñoz-Serrano, A. \& Alonso-Moraga, A., 2005. Genotoxicity and anti-genotoxicity of some traditional medicinal herbs. Mutat. Res. Genet. Toxicol. Environ. Mutagen. 585(1-2), 147-155

Rotondo, S., Rajtar, G., Manarini, S., Celardo, A., Rotilio, D., De Gaetano, G., Evangelista, V. \& Cerletti, C., 1998. Effect of trans-resveratrol, a natural polyphenolic compound, on human polymorphonuclear leukocyte function. Br. J. Pharmacol. 123(8), 1691-1699.

Ruan, B.F., Lu, X.Q., Song, J. \& Zhu, H.L., 2012. Derivatives of resveratrol: Potential agents in prevention and treatment of cardiovascular disease. Curr. Med. Chem. 19(24), 4175-4183.

Sacchi, K.L., Bisson, L.F. \& Adams, D.O., 2005. A review of the effect of winemaking techniques on phenolic extraction in red wines. Am. J. Enol. Vitic. 56(3), 197-206

Schieber, A., Stintzing, F. \& Carle, R., 2001. By-products of plant food processing as a source of functional compounds - recent developments. Trends Food Sci. Technol. 12(11), 401-413.

Shi, J., Yu, J. Pohorly, J.E. \& Kakuda, Y., 2003. Polyphenolics in grape seeds - biochemistry and functionality. J. Med. Food 6(4), 291-299.

Signorelli, P. \& Ghidoni, R., 2005. Resveratrol as an anticancer nutrient: Molecular basis, open questions and promises. J. Nut. Bioch. 16(8), 449466 .

Soleas, G.J., Diamandis, E.P. \& Goldberg, D.M., 1997. Wine as a biological fluid: History, production, and role in disease prevention. J. Clin. Lab. Anal. 11(5), 287-313.

Stagos, D., Kazantzoglou, G., Theofanidou, D., Kakalopoulou, G., Magiatis, P., Mitaku, S. \& Kouretas, D., 2006. Activity of grape extracts from Greek varieties of Vitis vinifera against mutagenicity induced by bleomycin and hydrogen peroxide in Salmonella typhimurium strain TA102. Mutat. Res. Genet. Toxicol. Environ. Mutagen. 609(2), 165-175.

Stervbo, U., Vang, O. \& Bonnesen, C., 2006. Time- and concentrationdependent effects of resveratrol in HL-60 and HepG2 cells. Cell Prolif. $39(6), 479-493$

Subbaramaiah, K., Michaluart, P., Chung, W.J., Tanabe, T., Telang, N. \& Dannenberg, A.J., 1999. Resveratrol inhibits cyclooxygenase-2 transcription in human mammary epithelial cells. Ann. N. Y. Acad. Sci. 889, 214-223.

Thimothe, J., Bonsi, I.A., Padilla-Zakour, O.I. \& Koo, H., 2007. Chemical characterization of red wine grape (Vitis vinifera and Vitis interspecific hybrids) and pomace phenolic extracts and their biological activity against Streptococcus mutans. J. Agric. Food Chem. 55(25), 10200-10207.

Van Balen, J., 1984. Recovery of anthocyanins and other phenols from converting grapes into wine. $\mathrm{PhD}$ dissertation, University of California Davis, CA, USA.

Yan, J., Huen, D., Morely, T., Johnson, G., Gubb, D., Roote, J. \& Adler, P.N., 2008. The multiple-wing-hairs gene encodes a novel GBD-FH3 domain-containing protein that functions both prior to and after wing hair initiation. Genetics 180(1), 219-228.

Zhan, Q., Lord, K.A., Alamo, Jr., I., Hollander, M.C., Carrier, F., Ron, D., Kohn, K.W., Hoffman, B., Liebermann, D.A. \& Fornace, Jr., A.J., 1994. The gadd and MyD genes define a novel set of mammalian genes encoding acidic proteins that synergistically suppress cell growth. Mol. Cell. Biol. 14(4), 2361-2371

Zhu, W., Qin, W., Zhang, K., Rottinghaus, G.E., Chen, Y.C., Kliethermes, B. \& Sauter, E.R., 2012a. Trans-resveratrol alters mammary promoter hypermethylation in women at increased risk for breast cancer. Nutr. Cancer 64(3), 393-400.

Zhu, L., Zhang, Y. \& Lu, J. 2012b. Phenolic contents and compositions in skins of red wine grape cultivars among various genetic backgrounds and originations. Int. J. Mol. Sci. 13(3), 3492-3510. 